\title{
Effect of Weaning on Serum Lipoprotein(a) Concentration: The STRIP Baby Study
}

\author{
TAINA ROUTI, TAPANI RÖNNEMAA, HELENA LAPINLEIMU, PIA SALO, JORMA VIIKARI, \\ AILA LEINO, ILKKA VÄLIMÄKI, EERO JOKINEN, AND OLLI SIMELL
}

The Cardiorespiratory Research Unit [T. Routi, H.L., P.S., I.V.] and Departments of Pediatrics [T. Routi, H.L., P.S., I.V., E.J., O.S.] and Medicine [T. Rönnemaa, J.V.], University of Turku and the Research and Development Unit of the Social Insurance Institution [T. Rönnemaa, A.L.], Turku, Finland

formula only (median increases 37,26 , and $20 \mathrm{mg} / \mathrm{L}$, respectively; $p=0.0062$ ). Thus the serum Lp(a) concentration was similar in all feeding groups at 13 mo. This finding was also observed at 24 and 36 mo. The increase in serum Lp(a) concentration was independent of the baseline $\mathrm{Lp}(\mathrm{a})$ level, apolipoprotein $E$ phenotype, gender, and weight gain of the infants between 7 and 13 mo. The results imply that weaning from breast milk influences markedly serum $\mathrm{Lp}(\mathrm{a})$ concentration, suggesting the presence of a $\mathrm{Lp}$ (a) lowering factor in breast milk. (Pediatr Res 38: 522-527, 1995)
$\mathbf{L p}(\mathbf{a})$, lipoprotein(a)
apo, apolipoprotein
BMI, body mass index

Abbreviations
The composition of $\mathrm{Lp}(\mathrm{a})$ resembles that of $\mathrm{LDL}$, but the protein moiety contains a unique glycoprotein apo(a) attached to apo B100 by disulfide bonds. Apo(a) is structurally and immunochemically related to plasminogen (1). The physiologic function of $\mathrm{Lp}(\mathrm{a})$ is obscure $(2,3)$, but in Caucasians a high serum $\mathrm{Lp}(\mathrm{a})$ concentration ( $\geq 250-300 \mathrm{mg} / \mathrm{L}$ ) is probably associated with increased risk for coronary artery disease $(4,5)$

Serum $\mathrm{Lp}(\mathrm{a})$ concentration is strongly influenced by genetic determinants. The concentration is inversely related to the size of the inherited apo(a) allele(s). Currently, some 34 apo(a) isoforms have been described (6). Serum $\mathrm{Lp}$ (a) concentration is independent of age and gender in adults, and commonly used

Received November 22, 1994; accepted April 25, 1995.

Correspondence and reprint requests: Taina Routi, M.D., Cardiorespiratory Research Unit, University of Turku, Kiinamyllynkatu 10, SF-20520 Turku, Finland.

Supported by grants from the Turku University Foundation, the Cardiac Research Foundation, Finland, Yrjö Jahnsson Foundation, the Varsinais-Suomi Fund of the Finnish Cultural Foundation, Arvo and Inkeri Suominen Fund, Lydia Maria Julin Fund, the Medical Council of the Finnish Academy, Juho Vainio Foundation, the Foundation for Pediatric Research, Finland, the Mannerheim League for the Wellfare of Children, Chymos Ltd., and van den Bergh Foods, Finland. lipid-lowering drugs and diets enriched with mono- and polyunsaturated fatty acids have not significantly diminished the serum $\mathrm{Lp}(\mathrm{a})$ concentration (7-9). In two preliminary studies supplementation of fish oil in capsule form in hypertriglyceridemic subjects and in one study palm oil has lowered serum Lp(a) concentrations (10-12). Interestingly, a high fat meal does not even temporarily increase the serum $L p(a)$ concentration (13).

Factors which influence serum $\mathrm{Lp}(\mathrm{a})$ concentration in early childhood are poorly known. Children who are $\geq 10 \mathrm{y}$ old and live in families where one parent has coronary heart disease have significantly higher serum $\mathrm{Lp}(\mathrm{a})$ concentrations than children of healthy parents $(5,14)$. In the Bogalusa Heart Study, Caucasian children with parental history of myocardial infarction had markedly higher serum $\mathrm{Lp}$ (a) concentration than children of healthy families. Furthermore, black children had higher $\mathrm{Lp}$ (a) levels than white children, but they did not show the Caucasian association between parent's coronary artery disease and high serum $\mathrm{Lp}(\mathrm{a})$ concentration (15).

Breast milk's concentration of cholesterol and saturated fat is high. Consequently, infants fed solely breast milk (16) or 
mixed food and breast milk (17) have higher serum cholesterol concentration than infants fed formula, and weaning inhibits the age-related increase in serum cholesterol values (16). Meanwhile, serum Lp(a) concentration is lower in infants who receive breast milk as the only milk source than in infants who receive formula at the age of $7 \mathrm{mo}$ (17).

We have now assessed the effect of weaning on serum $L p(a)$ concentration to obtain more definite proof of the possible $\mathrm{Lp}$ (a)-regulating effect of breast milk by measuring serum $\mathrm{Lp}$ (a) concentration in 414 healthy infants at the ages of 7, 13, and $24 \mathrm{mo}$ and in most of them also at $36 \mathrm{mo}$ of age, and compared changes in serum $\mathrm{Lp}(\mathrm{a})$ to changes in serum cholesterol concentration.

\section{METHODS}

Beginning in March 1990, 1062 healthy 6-mo-old infants (56.2\% of the eligible age cohort) were recruited in an intervention study for prevention of atherosclerosis (the STRIP baby project, Special Turku coronary Risk factor Intervention Project for babies). Recruiting was done by nurses at the well baby clinics in the city of Turku. At the Cardiorespiratory Research Unit a pediatrician met the parents and explained the background, purpose, and design of the study. The infants were divided randomly into an intervention and a control group. The intervention group received individualized dietary counseling which aimed at adequate energy supply with $30-35 \%$ of energy from fat and a polyunsaturated:monounsaturated:saturated fatty acid ratio of $1: 1: 1$, and cholesterol intake $<200 \mathrm{mg} /$ day.

All infants had received increasing amounts of solid food since the age of 3-5 mo. Based on the type of liquid milk the infants used at the age of 7 mo groups which received only breast milk ( $n=148)$, breast milk and formula $(n=74)$, or formula only ( $n=191$ ) were formed. Because the effect of weaning on serum $\mathrm{Lp}$ (a) level was similar in the intervention and control groups of the project, results of the intervention and control group infants were combined for analyses of the effects of the milk type used. Serum Lp(a) values of the parents of solely breast or formula-fed infants were also measured to exclude the possibility that the breast- and formula-fed infants differed genetically from each other.

Fifteen infants were fed cow's milk already at 7 mo of age; their data were excluded from this analysis. At the age of 13 mo all children received as their milk source cow's milk; the fat content of the milk used ranged from 0 to $3.9 \%$.

Venous nonfasting blood samples were successfully drawn for measurement of serum $\mathrm{Lp}(\mathrm{a})$ and cholesterol concentration at the ages of 7, 13, and 24 mo from 414 children. Until now, 341 of these children blood was obtained also at 36 mo of age. Samples were collected under cutaneous anesthesia with Emla (Astra, Södertälje, Sweden), separated by centrifugation (3500 $\mathrm{rpm}$ ) and stored at $-25^{\circ} \mathrm{C}$ before analyses within $2 \mathrm{mo}$, a time known to be without any effect on serum $\mathrm{Lp}(\mathrm{a})$ concentration (18). Lp(a) concentration was measured using a solid phase two-site immunoradiometric assay (Pharmacia, Uppsala, Sweden) based on direct sandwich technique in which two MAb are directed against separate antigenic determinants on the apo(a) molecule (19). Serum plasminogen concentration up to $5 \mathrm{~g} / \mathrm{L}$ gives no measurable cross-reactivity in the assay. The detection limit of the assay was $12 \mathrm{mg} / \mathrm{L}$, and the intraassay (interassay) coefficients of variation for the determination were $1.9 \%(4.4 \%)$ at $180 \mathrm{mg} / \mathrm{L}$, and $2.3 \%(4.9 \%$ ) at $45 \mathrm{mg} / \mathrm{L}$. Serum cholesterol concentration was analyzed with a fully enzymatic CHOD-PAP method (Merck, Darmstadt, Germany) (20). The intraassay (interassay) coefficient of variation for cholesterol was $1.5 \%(2.0 \%)$ at $4.5 \mathrm{mmol} / \mathrm{L}$. Weight-for-height of the infants was expressed as percentages of the mean weight-forheight of healthy Finnish children at the ages of 7 or 13 mo (21). Apo E phenotype was determined by isoelectric focusing (22).

The study has been approved by the Joint Ethics Committee of the University of Turku and Turku University Hospital. Informed consent was obtained from the parents of the children.

Because of the skewed distribution of $\mathrm{Lp}$ (a) concentrations and frequently encountered values which were below the detection limit of the assay (e.g. at 7 mo in $31.8 \%$ of breast-fed and $20.3 \%$ of formula-fed infants), median values were used. The significancies of the differences between the groups and the changes between 7 and 13,24, and 36 mo of age were tested using Kruskall-Wallis test and Wilcoxon rank sum test, respectively. Serum cholesterol concentrations were expressed as means $\pm \mathrm{SD}$; in their statistical analyses a $t$ test was used.

\section{RESULTS}

There was a pronounced increase in the infants' median $\mathrm{Lp}(\mathrm{a})$ concentration between 7 and 13 mo of age $(p<0.0001)$ (Table 1). The largest increase in median values $(37 \mathrm{mg} / \mathrm{L})$ occurred in infants who had received breast milk as their only milk source at 7 mo of age; the increase was smallest $(20$ $\mathrm{mg} / \mathrm{L}$ ) in infants who had received formula, and intermediate $(26 \mathrm{mg} / \mathrm{L})$ in those who had received both formula and breast milk at 7 mo of age. A slight but significant decrease in median $\mathrm{Lp}(\mathrm{a})$ values occurred in all three feeding groups between the ages of 13 and $24 \mathrm{mo}$. These changes were similar in the three groups. The values remained almost unchanged between 24 and 36 mo. All three feeding groups had a similar median $\mathrm{Lp}$ (a) concentration at $13 \mathrm{mo}$, as well as 24 and 36 mo of age. There was no difference in the dietary composition with respect to the percentage of polyunsaturated, monounsaturated, and saturated fat intake as measured by 3-4-d dietary records between the initially breast-fed infants and formula-fed infants at the ages of 13 and 24 mo.

The medians of the mid-parent serum $L p(a)$ values of those infants who had received breast milk or formula as their only milk source at $7 \mathrm{mo}$ of age were $113.5 \mathrm{mg} / \mathrm{L}$ and $112.5 \mathrm{mg} / \mathrm{L}$, respectively, $(p=0.92)$. This finding excludes the possibility that genetic differences in $\mathrm{Lp}(\mathrm{a})$ isoforms could explain the differences in the $\mathrm{Lp}(\mathrm{a})$ values between the breast milk-fed and the formula-fed groups. Serum cholesterol concentrations as well as BMI of the mothers and fathers in both feeding groups were similar, suggesting that there were no major differences in the nutrition between the parents in the two groups (serum 
Table 1. Serum Lp(a) concentration in children at 7, 13,24, and 36 mo according to milk type fed at 7 mo of age (BM= breast milk, $F=$ infant formula)

\begin{tabular}{|c|c|c|c|c|}
\hline & \multicolumn{3}{|c|}{ Milk type at $7 \mathrm{mo}$} & \multirow{2}{*}{$\begin{array}{c}p \text { for difference } \\
\text { between the groups }\end{array}$} \\
\hline & $\mathrm{BM}(n=148)$ & $\mathrm{BM}+\mathrm{F}(n=74)$ & $\mathrm{F}(n=192)$ & \\
\hline Median value at $7 \mathrm{mo}(\mathrm{mg} / \mathrm{L})$ (range) & $\begin{array}{c}25 \\
(\leq 12-743)\end{array}$ & $\begin{array}{c}35 \\
(\leq 12-1188)\end{array}$ & $\begin{array}{c}45 \\
(\leq 12-577)\end{array}$ & $\begin{array}{l}\text { overall } 0.0013 \\
\mathrm{BM} v s \mathrm{~F} 0.0003\end{array}$ \\
\hline Median value at $13 \mathrm{mo}(\mathrm{mg} / \mathrm{L})$ (range) & $\begin{array}{c}67^{*} \\
(\leq 12-1605)\end{array}$ & $\begin{array}{c}62^{*} \\
(\leq 12-1880)\end{array}$ & $\begin{array}{c}80^{*} \\
(\leq 12-1125)\end{array}$ & NS \\
\hline Median value at $24 \mathrm{mo}(\mathrm{mg} / \mathrm{L})$ (range) & $\begin{array}{c}51 \dagger \\
(\leq 12-1495)\end{array}$ & $\begin{array}{c}59 \dagger \\
(\leq 12-1495)\end{array}$ & $\begin{array}{c}65 \dagger \\
(\leq 12-1295)\end{array}$ & NS \\
\hline Median value at $36 \mathrm{mo}(\mathrm{mg} / \mathrm{L})$ (range) & $\begin{array}{c}53 \ddagger \\
(\leq 12-1620)\end{array}$ & $\begin{array}{c}55 \ddagger \\
(\leq 12-928)\end{array}$ & $\begin{array}{c}59 \ddagger \\
(\leq 12-898)\end{array}$ & NS \\
\hline \multicolumn{5}{|l|}{ Median change in absolute values $(\mathrm{mg} / \mathrm{L})$} \\
\hline From 7 to $13 \mathrm{mo}$ & +37 & +26 & +20 & $\begin{array}{c}\text { overall } 0.0062 \\
\mathrm{BM} v s \mathrm{~F} 0.0024\end{array}$ \\
\hline From 13 to $24 \mathrm{mo}$ & -6 & -5 & -7 & NS \\
\hline From 24 to $36 \mathrm{mo}$ & +3 & +2 & +1 & NS \\
\hline \multicolumn{5}{|l|}{ Relative change in median values (\%) } \\
\hline From 7 to $13 \mathrm{mo}$ & +122 & +67 & +44 & $\begin{array}{c}\text { Overall }<0.0001 \\
\mathrm{BM} \text { vs } \mathrm{F}<0.0001\end{array}$ \\
\hline From 13 to $24 \mathrm{mo}$ & -10 & -7 & -12 & NS \\
\hline From 24 to $36 \mathrm{mo}$ & +8 & +7 & +6 & NS \\
\hline
\end{tabular}

Difference within groups:

* Between $L p(a)$ values at 7 and 13 mo of age, $p<0.0001$, sign rank test.

$\uparrow$ Between $L p(a)$ values at 7 and 24 mo of age, $p<0.0001$, sign rank test.

$\ddagger$ Between $L p(a)$ values at 13 and 24 mo of age, $p<0.0001$ in children fed only breast milk or only formula at the age of 7 mo, $p=0.024$ in children fed both breast milk and formula at the age of 7 mo.

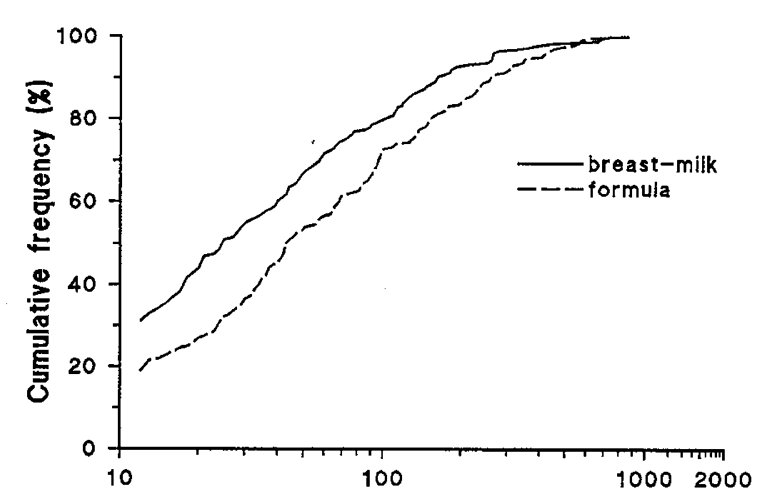

Serum Lp(a) (mg/l, log. scalo) at 7 months

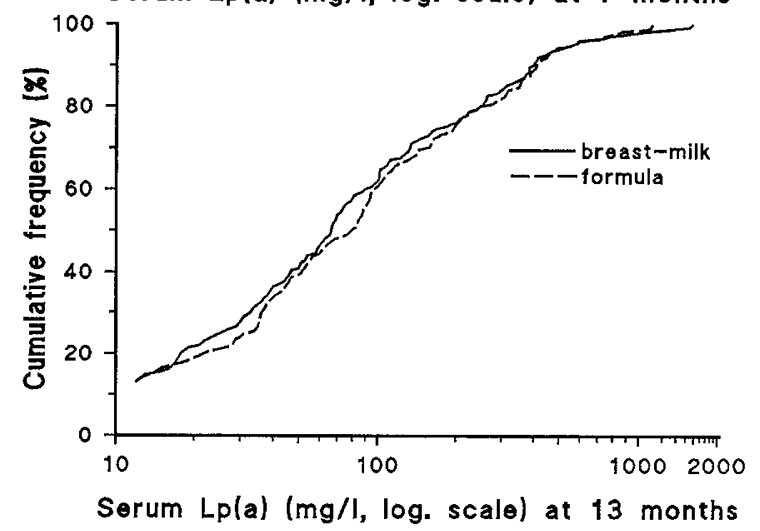

Figure 1. Cumulative distribution of serum $\mathrm{Lp}(\mathrm{a})$ concentrations in infants at 7 mo of age (top) and at 13 mo of age (bottom).

cholesterol in mothers of the breast-fed infants $5.02 \pm 0.86$ $\mathrm{mmol} / \mathrm{L}$ and in mothers of formula-fed infants $5.08 \pm 1.05$ $\mathrm{mmol} / \mathrm{L} ; p=0.56$. The respective values in fathers were 5.37 \pm 1.04 and $5.40 \pm 1.10 \mathrm{mmol} / \mathrm{L} ; p=0.78$. BMI in mothers of breast-fed infants $23.0 \pm 3.2 \mathrm{~kg} / \mathrm{m}^{2}$ and in mothers of formulafed infants $23.6 \pm 3.7 \mathrm{~kg} / \mathrm{m}^{2} ; p=0.09$. The respective values in fathers were $24.9 \pm 3.2$ and $24.8 \pm 3.2 \mathrm{~kg} / \mathrm{m}^{2} ; p=0.60$ )

The cumulative distributions of $\mathrm{Lp}$ (a) concentrations, which had differed markedly between breast- and formula-fed groups at $7 \mathrm{mo}$, showed no differences between the two groups at 13 mo of age (Fig 1). The distribution curves at the ages of 24 and 36 mo were almost identical to those at 13 mo of age.

Because of the expected influence of genetic factors on serum $L p(a)$ concentration, we subdivided the infants in the breast- and formula-fed groups into infants with $\mathrm{Lp}$ (a) values $<37 \mathrm{mg} / \mathrm{L}$ (median for age) or $\geq 37 \mathrm{mg} / \mathrm{L}$ at the age of $7 \mathrm{mo}$ (Table 2). The differences between the breast milk-fed and formula-fed groups in absolute and relative changes which occurred in the $L p(a)$ values between 7 and 13 mo of age were significant irrespective of the 7-mo $\mathrm{Lp}$ (a) level [high versus low $\mathrm{Lp}(\mathrm{a})]$.

The age-associated increases in serum $\mathrm{Lp}$ (a) values differed significantly between the two feeding groups (breast milk and formula) in boys as well as in girls. In boys the median increase in serum $L p(a)$ among breast-fed infants was $31 \mathrm{mg} / \mathrm{L}(112 \%)$ and in formula-fed infants $17 \mathrm{mg} / \mathrm{L}(41 \%$; $p$ for difference in change $<0.001$ ). The respective figures in girls were $37 \mathrm{mg} / \mathrm{L}$ $(112 \%)$ and $24 \mathrm{mg} / \mathrm{L}$ (46\%; $p$ for difference in change $<0.001$ ).

The mean increases in height, relative weight, and weightfor-height between 7 and 13 mo of age were similar in the breast milk, breast milk and formula, and formula groups (data not shown). Because growth may influence $L p(a)$ values, the infants were divided into growth rate quartiles which were based on their relative weight increases between 7 and 13 mo of age. In all quartiles, the differences between breast milk-fed and formula-fed infants in the changes which were recorded 
Table 2. Absolute and relative changes in serum $L p(a)$ concentration between 7 and 13 mo of age who were fed breast milk or formula as their only milk source at $7 \mathrm{mo}$, stratified according to serum Lp(a) concentration $(<$ or $\geq$ median $=37 \mathrm{mg} / \mathrm{L})$ at $7 \mathrm{mo}$

\begin{tabular}{lccccc}
\hline & \multicolumn{2}{c}{$\mathrm{Lp}(\mathrm{a})<$ median at $7 \mathrm{mo}$} & & \multicolumn{2}{c}{ Lp(a) $\geq$ median at $7 \mathrm{mo}$} \\
\cline { 2 - 5 } \cline { 5 - 6 } & $\begin{array}{c}\text { Breast milk-fed at } 7 \text { mo } \\
\text { of age }(n=100)\end{array}$ & $\begin{array}{c}\text { Formula-fed at } 7 \text { mo of } \\
\text { age }(n=107)\end{array}$ & $\begin{array}{c}\text { Breast milk-fed at } 7 \text { mo } \\
\text { of age }(n=73)\end{array}$ & $\begin{array}{c}\text { Formula-fed at } 7 \text { mo of } \\
\text { age }(n=135)\end{array}$ \\
\hline Median absolute change $(\mathrm{mg} / \mathrm{L})$ & +19 & $+5^{*}$ & $+26 \ddagger$ & +121 & $+48 \dagger$ \\
Median relative change $(\%)$ & +109 & +24 & $+49 \S$ \\
\hline
\end{tabular}

Difference between breast milk-fed and formula-fed infants:

${ }^{*} p=0.003$.

$\dagger p<0.0001$.

$\ddagger p=0.0006$.

$\S p<0.0001$.

in the $L p(a)$ values between 7 and 13 mo were significant (Table 3).

The infants were also divided into two groups according to their apo $\mathrm{E}$ phenotype: infants with apo $\epsilon 4$ allele (apo E $4^{+}$) and infants without apo $\epsilon 4$ allele (apo $\mathrm{E}^{-}$). In both groups the increase in serum $L p(a)$ concentration between 7 and 13 mo was significantly higher in breast-fed infants than in formulafed infants (Table 4). Within the milk groups there was no difference in the change in serum $\mathrm{Lp}(\mathrm{a})$ levels between the apo $\mathrm{E}^{+}{ }^{+}$and apo $\mathrm{E} 4^{-}$infants. In breast-fed children with apo $\mathrm{E} 2 / \mathrm{E} 2$ or $\mathrm{E} 3 / \mathrm{E} 2$ phenotype $(n=16) \mathrm{Lp}(\mathrm{a})$ concentration rose after weaning from $33.5 \mathrm{mg} / \mathrm{L}$ to $88 \mathrm{mg} / \mathrm{L}$, and the median increase was $121 \%$, which was not different from the increase in all breast-fed children (median increase 122\%).

Interestingly, the changes between 7 and 13 mo of age in serum cholesterol concentration were different from the changes in serum $\mathrm{Lp}$ (a) concentration in all groups of infants which were formed according to milk type used at $7 \mathrm{mo}$ of age. Mean serum cholesterol remained unchanged (mean \pm SD at 7 mo $4.1 \pm 0.78 \mathrm{mmol} / \mathrm{L}$ and at $13 \mathrm{mo} 4.11 \pm 0.77 \mathrm{mmol} / \mathrm{L}$; $p=\mathrm{NS}$ ) in the infants who had been breast-fed at $7 \mathrm{mo}$, and increased by $0.30 \mathrm{mmol} / \mathrm{L}$ (from $3.76 \pm 0.69$ at $7 \mathrm{mo}$ to $4.06 \pm 0.68 \mathrm{mmol} / \mathrm{L}$ at $13 \mathrm{mo} ; p<0.001)$ in the infants who had been formula-fed at 7 mo ( $p$ for the difference in the change between the groups $<0.0001)$. Indeed, the changes in serum $\mathrm{Lp}(\mathrm{a})$ concentration did not correlate with the changes in serum cholesterol concentration neither in the infants fed breast

Table 3. Relative change (\%) in serum $L p($ a) concentration in infants who received breast milk or formula as their only source of milk at 7 mo of age stratified according to the change in relative weight between 7 and 13 mo of age

\begin{tabular}{lcccc}
\hline & \multicolumn{5}{c}{ Quartiles of change in relative } \\
& \multicolumn{4}{c}{ weight* } \\
\cline { 2 - 5 } Change & I & II & III & IV \\
\hline Absolute change $(\mathrm{mg} / \mathrm{L})$ & & & & \\
$\quad$ Breast-fed at 7 mo of age & +48 & +28 & +34 & +23 \\
$\quad$ Formula-fed at 7 mo of age & +13 & +24 & +22 & +21 \\
$p \dagger$ & $<0.001$ & $<0.001$ & 0.005 & 0.018 \\
Relative change (\%) & & & & \\
$\quad$ Breast-fed at 7 mo of age & +157 & +117 & +112 & +87 \\
Formula-fed at 7 mo of age & +33 & +48 & +47 & +41 \\
$p$ & 0.001 & $<0.001$ & 0.01 & 0.008 \\
\hline
\end{tabular}

* I quartile represents the smallest and IV quartile the largest increase in the relative weight between 7 and 13 mo of age.

$\dagger$ Wilcoxon rank sum test after logarithmic transformation. milk $(r=0.064, p=\mathrm{NS})$ nor in the infants fed formula $(r=$ $0.081, p=\mathrm{NS})$. At $13 \mathrm{mo}$ and later, mean serum cholesterol concentrations and the changes in serum cholesterol concentration were similar in both groups (data not shown).

\section{DISCUSSION}

We showed previously in a large cohort of infants that those who received breast milk as their only milk source had significantly lower serum $\mathrm{Lp}(\mathrm{a})$ concentration than those who received formula (17). On the other hand, Van Biervliet et al. (23) in a sample of 27 children found no difference in serum $\mathrm{Lp}(\mathrm{a})$ between infants fed breast milk or formula at the age of 3 mo. The current study is in accordance with our previous findings showing in a sample of 414 infants that the age-related increase in $\mathrm{Lp}(\mathrm{a})$ is higher when the infants switch to adult-like diet from breast milk than when they switch from feeding which is based on formula. Furthermore, the increase was intermediate in the group which switched from a diet which included both breast milk and formula. Breast milk-associated factors thus influence serum $\mathrm{Lp}(\mathrm{a})$ concentrations markedly, but the influence is transient.

Boerwinkle et al. (24) have shown that the apo(a) gene mainly accounts for the variance in plasma $\mathrm{Lp}(\mathrm{a})$ concentration in the adult population. Therefore, one might argue that there could be a possible genetic predisposition for lower $\mathrm{Lp}(\mathrm{a})$ levels in breast-fed infants. However, we have two arguments against this possibility: first, the difference in change in serum $\mathrm{Lp}$ (a) concentration between breast-fed and formula-fed infants was independent of the baseline $L p(a)$ value; and second, the parents of breast-fed and formula-fed infants had similar median mid-parent values of serum $L p(a)$ concentrations. In adults, some dietary factors may also affect serum $L p(a)$ levels $(10-12,25,26)$. Therefore, there is a theoretical possibility that serum $\mathrm{Lp}$ (a) levels in parents of breast- and formula-fed infants could be similar as a result of different nutrition acting in opposite directions. However, there was no difference in serum total cholesterol concentrations and BMI values between the parents of breast-fed and formula-fed infants; these rough estimates of nutrition suggest that there were no major dietary differences between the parents in the two feeding groups. Our findings clearly imply that exogenic factors also influence $\mathrm{Lp}$ (a) levels in early childhood. This regulation might in theory be mediated by nutritional components, or hormones and growth factors (27) in the breast milk that may inhibit synthesis 


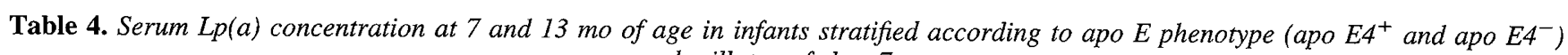

\begin{tabular}{|c|c|c|c|c|}
\hline & \multicolumn{3}{|c|}{ Milk type fed at 7 mo of age } & \multirow{2}{*}{$\begin{array}{c}p \text { for difference between } \\
\text { the groups }\end{array}$} \\
\hline & $n$ (Breast/formula) & Breast milk only & Formula only & \\
\hline \multicolumn{5}{|c|}{ Median value at $7 \mathrm{mo}(\mathrm{mg} / \mathrm{L})$ (range) } \\
\hline Apo E4 ${ }^{+}$ & $69 / 75$ & $30(\leq 12-743)$ & $50(\leq 12-559)$ & 0.010 \\
\hline Apo E4- & $98 / 157$ & $21(\leq 12-676)$ & $40(\leq 12-862)$ & 0.0041 \\
\hline \multicolumn{5}{|c|}{ Median value at $13 \mathrm{mo}(\mathrm{mg} / \mathrm{L})$ (range) } \\
\hline Apo $\mathrm{E}^{+}$ & $69 / 75$ & $72(\leq 12-1300)$ & $87(\leq 12-1125)$ & 0.56 \\
\hline Apo E4- & $98 / 157$ & $66(\leq 12-1605)$ & $68(\leq 12-1120)$ & 0.50 \\
\hline \multicolumn{5}{|c|}{ Median absolute change (mg/L) } \\
\hline Apo E4 ${ }^{+}$ & & +40 & +25 & 0.036 \\
\hline Apo E4- & & +28 & +16 & 0.025 \\
\hline \multicolumn{5}{|c|}{ Median relative change (\%) } \\
\hline Apo $\mathrm{E}^{+}$ & & +124 & +51 & $<0.0001$ \\
\hline Apo $\mathrm{E}^{-}$. & & +108 & +38 & $<0.0001$ \\
\hline
\end{tabular}

or accelerate degradation of the $\mathrm{Lp}(\mathrm{a})$ particles. The possible active components of breast milk are discussed below in detail.

$\mathrm{Lp}$ (a) concentrations which are low at birth, often below the detection level of the current assay methods, increase during the first year of life, and reach adult concentrations during the second year $(28,29)$. Intestinal mucosa matures and intestinal permeability decreases during the first year of life (30). This change in intestinal leakiness might explain why breast milk feeding influences serum $\mathrm{Lp}$ (a) concentrations in infancy, but nutritional changes, e.g. those examined in many intervention studies, have minimal effects on $\mathrm{Lp}$ (a) concentration later in life. Breast milk and formula differ in many nonprotein components but also in the protein composition. In particular, immunologically active proteins and growth factors differ (27), and these differences are at least in theory possible factors behind the differences in the effect between the two milk types on serum $\mathrm{Lp}(\mathrm{a})$. However, the increased permeability of the intestinal mucosa to proteins disappears usually between 0 and 6 mo of age, and major changes in the leakiness are unlikely to occur as late as between 7 and 13 mo of age.

Significant differences in the fatty acid composition of breast milk and infant formula do exist. Large amounts of trans-fatty acids in the diet increase serum Lp(a) levels in adults $(25,26)$, but the trans-fatty acid concentration in human milk (31) and in the most commonly used infant formula in Finland are closely similar (4.4 and 4.7\%, respectively). Therefore, differences in trans-fatty acid intake are an unlikely explanation for our findings.

Breast milk contains significantly more gestagenic hormones than formula (32). Use of norethisterone, a synthetic gestagen, is associated with a decreased concentration of serum $\mathrm{Lp}(\mathrm{a})$ in postmenopausal women (33). These findings suggest that hormones in breast milk may at least to some extent account for its $\mathrm{Lp}(\mathrm{a})$ lowering effects.

Another factor which has been associated with decreases in serum $\mathrm{Lp}$ (a) concentrations in adults is weight loss, as in adult women weight loss decreases high ( $>300 \mathrm{mg} / \mathrm{L}$ ) serum $\mathrm{Lp}$ (a) concentrations (34). We found no difference in the change in Lp(a) concentrations between the children whose weight-forheight decreased and children whose weight-for-height increased between 7 and 13 mo of age when the growth rate is rapid.
Due to breast milk's high cholesterol and saturated fat content, serum cholesterol concentration was higher in infants who received breast milk as their only milk source than in infants who received formula at $7 \mathrm{mo}$ of age. Serum cholesterol concentration remained unchanged in infants who were weaned from breast milk between 7 and 13 mo of age, but increased markedly in infants who had been fed formula at 7 mo of age. The changes in serum cholesterol were thus different from those in serum $L p(a)$, suggesting that the serum $L p(a)$ concentration is regulated independently from serum cholesterol in infants. The effect of breast milk on $\mathrm{Lp}$ (a) seems to be transient, because of the lack of difference between the groups in the later measurements. Similarly, breast milk probably has no long-term effects on cholesterol in children (35), although in animal studies differences in cholesterol metabolism later in life have been reported (36).

In summary, our results show that breast milk feeding has marked effects on the serum $L p(a)$ concentration in infants and that differences in serum $\mathrm{Lp}(\mathrm{a})$ concentration between previously breast milk fed and formula-fed infants disappear rapidly after weaning. We hypothesize that breast milk hormones or growth factors are responsible for the difference between the $\mathrm{Lp}$ (a) levels in the breast milk-fed and formula-fed infants. The biologic significance of the decreased serum $\mathrm{Lp}$ (a) values due to breast milk feeding is unknown with regard to initiation of atherogenesis. However, knowing that earliest precursors of atherosclerosis, fatty streaks, can develop during the first years of life, a potentially favorable effect of low $\mathrm{Lp}$ (a) during the first 12 mo of age cannot be excluded. After all, the main message of our finding is that, contrary to previous reports, physiologic dietary factors can affect serum Lp(a) levels.

\section{REFERENCES}

1. Karàdi I, Kostner GM, Gries A, Nimpf J, Romics L, Malle E 1988 Lipoprotein(a) and plasminogen are immunochemically related. Biochim Biophys Acta 960:91-97

2. Uterman G 1989 The mysteries of lipoprotein(a). Science 246:904-910

3. Howard GC, Pizzo SV 1993 Biology of disease. Lipoprotein(a) and its role in atherothrombotic disease. Lab Invest 69:373-386

4. Scanu AM 1992 Lipoprotein(a). A genetic risk factor for premature coronary heart disease. JAMA 267:3326-3329

5. Kostner GM, Czinner A, Pfeiffer KH, Bihari-Varga M 1991 Lipoprotein(a) concentrations as risk indicators for atherosclerosis. Arch Dis Child 66:1054-1056

6. Marcovina SM, Zhang ZH, Gaur VP, Albers JJ 1993 Identification of 34 apolipoprotein(a) isoforms: differential expression of apolipoprotein(a) alleles between American blacks and whites. Biochem Biophys Res Commun 191:1192-1196 
7. Gustafsson I-B, Vessby B, Nydahl M 1992 Effects of lipid-lowering diets enriched with monounsaturated and polyunsaturated fatty acids on serum lipoprotein composition in patients with hyperlipoproteinemia. Atherosclerosis 96:109-118

8. Malle E, Sattler W, Prenner E, Leis HJ, Hermetter A, Gries A, Kostner GM 1991 Effects of dietary fish oil supplementation on platelet aggregability and platelet membrane fluidity in normolipemic subjects with and without high plasma $\mathrm{Lp}(\mathrm{a})$ concentrations. Atherosclerosis 88:193-201

9. Kostner GM, Gavish D, Leopold B, Bolzano K, Weintraub MS, Breslow JL 1989 HMG CoA reductase inhibitors lower $\mathrm{LDL}$ cholesterol without reducing $\mathrm{Lp}(\mathrm{a})$ levels. Circulation 80:1313-1319

10. Hornstra G, van Houwelingen AC, Kester ADM, Sundram K 1991 A palm oilenriched diet lowers serum lipoprotein(a) in normocholesterolic volunteers. Atherosclerosis 90:91-93

11. Beil FU, Terres W, Orgass M, Greten H 1991 Dietary fish oil lowers lipoprotein(a) in primary hypertriglyceridemia. Atherosclerosis 90:95-97

12. Dallongeville J, Selinger E, Davignon J, Lussier-Cacan S 1992 Fish-oil supplementation reduces Lp(a) concentrations in type III dysbetalipoproteinemia. Clin Chem 38:1510-1211

13. Pfaffinger D, Schuelke J, Kim C, Fless GM, Scanu AM 1991 Relationship between apo(a) isoforms and $\mathrm{Lp}(\mathrm{a})$ density in subjects with different apo(a) phenotype: a study before and after a fatty meal. J Lipid Res 32:679-683

14. Vella JC, Jover E 1993 Relation of lipoprotein(a) in.11- to 19-year-old adolescents to parental cardiovascular heart disease. Clin Chem 39:477-480

15. Srinivasan SR, Dahlén GH, Jarpa RA, Webber LS, Berenson GS 1991 Racial (black-white) differences in serum lipoprotein(a) distribution and its relation to parental myocardial infarction in children. Circulation 84:160-167

16. Kallio MJT, Salmenperä L, Siimes MA, Perheentupa J, Miettinen TA 1992 Exclusive breast-feeding and weaning: effect on serum cholesterol and lipoprotein concentrations in infants during the first year of life. Pediatrics 89:663-666

17. Rönnemaa T, Routi T, Lapinleimu H, Viikari J, Leino A, Simell O 1994 Lp(a) concentration in 7-month old children in relation to breast-feeding. Nutr Metab Cardiovasc Dis 4:188-191

18. Panteghini M, Pagani F 1993: Pre-analytical, analytical, and biological sources of variation of lipoprotein(a). Eur J Clin Chem Clin Biochem 31:23-28

19. März W, Siekmeier R, Gross E, and Gross W 1993 Determination if lipoprotein(a): enzyme immunoassay and immunoradiometric assay compared. Clin Chim Acta 214:153-163

20. Siedel J, Schlumberger H, Klose S, Ziegenhorn J, and Wahlefeld AW 1981 Improved reagent for the enzymatic determination of serum cholesterol. J Clin Chem Clin Biochem 19:838-839
21. Sorva R, Tolppanen EM, and Perheentupa J 1990 Variation of growth in length and weight of children. I. Years 1 and 2. Acta Paediatr Scand 79:490-497

22. Lehtimäki T, Moilanen T, Viikari J, Åkerblom HK, Ehnholm C, Rönnemaa T, Marniemi J, Dahlen G, Nikkari T 1990 Apolipoprotein E phenotypes in Finnish youths; a cross-sectional and 6-year follow-up study. J Lipid Res 31:487-495

23. Van Biervliet JP, Labeur C, Michiels G, Usher DC, Rosseneu M 1991 Lipoprotein(a) profiles and evolution in newborns. Atherosclerosis 86:173-181

24. Boerwinkle E, Leffert CC, Jingping L, Lackner C, Chiesa G, Hobbs HH 1992 Apolipoprotein(a) accounts for more than $90 \%$ of the variation in plasma lipoprotein(a) concentrations. J Clin Invest 90:52-60

25. Nestel P, Noakes M, Belling B, McArthur R, Clifton P, Janus E, Abbey M 1992 Plasma lipoprotein lipid and Lp(a) changes with substitution of elaidic acid for oleic acid in the diet. J Lipid Res 33:1029-1036

26. Mensink RP, Zock PL, Katan MB, Hornstra G 1992 Effect of dietary cis and trans fatty acids on serum lipoprotein(a) levels in humans. J Lipid Res 33:1493-1501

27. Koldovský O, Thornburg W 1987 Hormones in milk (review). J Pediatr Gastroenterol Nutr 6:172-196

28. Wang XL, Wilcken DEL, Dudman NPB 1990 Neonatal apo A-I, apo B, and apo(a) levels in dried blood spots in an Australian population. Pediatr Res 28:496-501

29. Rifai N, Heiss G, Doetsch K 1992 Lipoprotein(a) at birth, in blacks and whites. Atherosclerosis 92:123-129

30. Milla Py 1986 The weanling's gut. Acta Paediatr Scand Suppl 323:5-13

31. Koletzko B, Mrotzek M, Bremer HJ 1988 Fatty acid composition of mature human milk in Germany. Am J Clin Nutr 47:954-959

32. Lauritzen C, Lehmann W-D 1967 Ausscheidung von Pregnandiol und Pregnanolon im Neugeborenenharn. Stimulierung durch Choriongonadotropin und ACTH. Arch Gynaekolog 204:197-211

33. Farish E, Rolton HA, Barnes JF, Hart DM 1991 Lipoprotein(a) concentrations in postmenopausal women taking norethisterone. Br Med J 303:694

34. Muls E, Kempen K, Vansant G, Cobbaert C, Saris W 1993 The effect of weight loss and apolipoprotein $\mathrm{E}$ polymorphism on serum lipids, apolipoprotein $\mathrm{A}-1$ and $\mathrm{B}$, and lipoprotein(a). Int J Obes 17:711-716

35. Hamosh J 1988 Does infant nutrition affect adiposity and cholesterol levels in the adult? J Pediatr Gastroenterol Nutr 7:10-16

36. Mott GE, Jackson EM, McMahan CA, McGill HC 1990 Cholesterol metabolism in adult baboons is influenced by infant diet. J Nutr 120:243-251 